\title{
ASSESSING INTERNATIONAL COMPETITIVENESS AND ITS ROLE TOWARDS THE ECONOMIC PROSPERITY WITHIN EU INTEGRATION FRAMEWORK
}

\author{
Jelena Stanojević* \\ Gabrijela Veličković**
}

Received: 20. 12. 2020

Original scientific paper

Accepted: 18. 4. 2021

UDC 339.137(4-67EU)

DOI https://doi.org/10.30924/mjcmi.26.si.3

\begin{abstract}
Enhancing competitiveness in the era of globalization has become an essential topic of academic and policy debates for all contemporary economies. The role of a country's competitiveness has been addressed by many scholars aiming to assess the extent to which this concept is associated with economic prosperity matters, such as social welfare and attracting foreign direct investments. Along with this debate, there has been a growing interest in understanding the linkages between the competitive forces and the gap in economic progress across the EU members, this being one of the main concerns within the EU. Filling this gap and achieving greater convergence among the EU countries has been one of the critical goals in shaping the European structural policy reforms. However, following the empirical findings, there has been little consensus on what are the main sources of a country's eco-

linkages with a country's international competitiveness. The focus is placed on innovation and business sophistication factors' relative significance and contribution to the economic growth for the observed period (2008-2017). The analysis is based on the World Economic Forum methodology for measuring the Global Competitiveness Index and World Bank database. The research is conducted through comparative analysis, as well as regression analysis aiming to evaluate the relationship between competitiveness and economic development indicators. The findings of the study emphasize a better understanding of the importance of the EU accession date for the country's overall competitiveness and economic performance, as well as the contribution of $R \& D$ innovation and business sophistication, as more advanced competitiveness factors, to economic prosperity and development.
\end{abstract} nomic progress as addressed through the prism of national competitiveness, particularly if being studied in the context of EU integration. In this context, the study aims to assess the economic performance of the countries that joined the EU first and those that joined last, concerning its
Keywords: economic performance, international competitiveness, competitiveness factors, research \& development, innovation, EU countries

\footnotetext{
* Jelena Stanojević, PhD (corresponding author), International Business College Mitrovica, Str. Bislim Bajgora nn, 40000 Mitrovica, Kosovo, E-mail: j.stanojevic@ibcmitrovica.eu

** Gabrijela Veličković, International Business College Mitrovica, Kosovo
} 


\section{Journal of Contemporary Management Issues}

\section{INTRODUCTION}

Over the last decades, market liberalization has been an overwhelming tendency in the world economy. The multidimensional implications of this trend, embodied in specialization and diversification, economies of scale, and dynamic international flow of goods, services, and production factors, along with the technological ones, have increased the complexity of contemporary economies and redefined the role of international competitiveness in assessing economic performance of countries worldwide (Kharlamova, 2013). Under such a scenario, being characterized with an intensified competition among the economic subjects at all levels (firm, regional and national), fostering economic prosperity of a country has become necessarily conditioned by the country's ability to play an important role in the international environment and the global marketplace.

The assessment of economic progress through the lens of the international competitiveness of a country has been controversial, giving birth to several views. While some, being pioneers of the economic school, even deny Porter's notion of country competitiveness, believing that countries do not compete internationally, comparable to enterprises (Krugman, 1994; Kohler, 2006), others, belonging to the management school, support such a concept, taking a variety of approaches to defining it. In this sense, several definitions equate national competitiveness with the country's productivity and growth. A different line of studies measures it by using the market share and external balances. Another group of scholars emphasizes the qualitative aspect of this concept, analyzing it from the perspective of gaining or losing technological advantage in particular industries. A broader notion of national competitiveness encompasses the assessment of social, economic, and environmental achievements of a country, given that having an increase in production and exports is limited in case of increased costs of social and environmental policy goals. Some explanations of the concept go even further, including the assessment of health, equity, education, leisure, and other qualitative factors when measuring competitiveness (Aiginger and Landesmann, 2002).

Aiming to explain the roots of some countries' economic success in specific industries, Porter (1990) pointed out the importance of four categories of a country's features, called a "national diamond" that are employed to determine its comparative advantage in an international framework. In addition to demand and factor conditions, as well as the business structure, rivalry, and strategy, Porter (1990) adds two additional factors, such as national policies and external distress to further explain the determinants of an economy's superiority. As seen by Porter (1990), factor conditions, being classified into the categories of fundamental and progressive, according to the investment requirements and possibilities for upgrading, have been identified as the core of a country's competitive advantage. Similarly, the demand features are identified as playing a determining role, where the demand differences, rather than similarities, are found to better justify the disparities in national competitiveness across countries and industries. As Porter (1990) suggests, the domestic demand structure is the one that creates the way, in which firms perceive and satisfy the customers' needs. Accordingly, the firms have an intention to constantly upgrade their offer and innovate to respond to high requirements, in terms of product and service features and to improve their competitive position. In this view, rivalry, which pushes businesses to be more efficient, enhance quality, and 
innovate, has been identified as a vital factor of firms' competitive advantage (Smit, 2010). The firm's strategy and structure, as explained by Porter (1990), strongly depend on the environment within the national market. Given that there are significant differences in the industrial structures, business environment, and strategies across different countries, affecting how businesses compete, this implies the existence of meaningful differences in their comparative superiority in the global market.

Competitiveness at the country level has been addressed by many scholars, aiming to assess the extent to which this concept is associated with the social welfare and economic progress of a country. Accordingly, several authors have tried to evaluate the relative importance of different factors and indicators of such competitiveness, looking into the differences between the countries' level of technological advancement and innovation capacity as indicators of the economy's development stage. Having an understanding of the national gaps in the technology and innovation status enables an understanding of which countries have economies based on efficiency, versus those, whose advancement and competitiveness are based on innovation (Tudose and Rusu, 2015).

According to the Global Competitiveness Ranking Reports (Schwab, 2014), a widely accepted measure used to assess cross-country competitiveness is the Global Competitiveness Index (GCI). The methodology applied in these reports is based on the assessment of different areas - reflected in the 12 pillars of national performance (see Figure 1). The 12 pillars are distributed to three sub-indices, each reflecting one source of the country's competitiveness (factors-driven, efficiency-driven, innovation-driven).

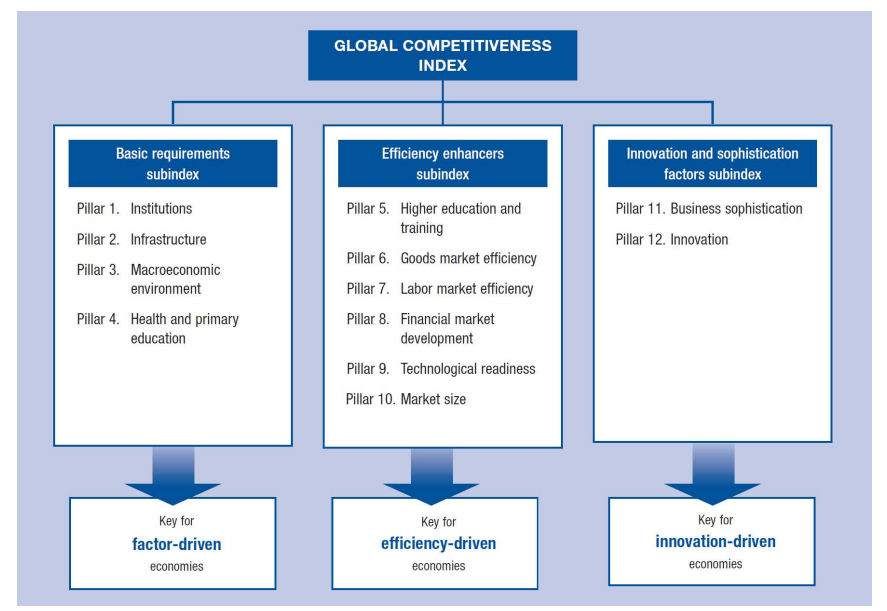

Figure 1. The Global Competitiveness Index framework

Source: Schwab (2014)

While the first category of indicators comprises the main production factors, the second group of indicators is reserved for the main efficiency drivers

within an economy. The third group of indicators measures the countries' commitment to innovation, based on a composite measure, rather than the extent to which a 


\section{Journal of Contemporary Management Issues}

country invests in Research \& Development (R\&D). According to this methodology, each country is awarded a value (running from 1 to 7), based on the performance being achieved within 12 different categories. The weighted average of the scores constitutes the ranking of a country, explaining the main source of its competitiveness (Priede and Neuert, 2015).

The concept of national competitiveness, as first developed by Porter (1998), suggests that there are three levels of a country's economic progress, each being determined by diverse competition measures, level of productivity, and income. This implies that each country is starting from the stage of the factor-based economy, goes through the stage of the investment-dependent economy, and ends up with the stage of innovation-driven economy, on its path towards achieving economic prosperity. Following this approach, World Economic Forum has upgraded this model, including two more transit stages in building economic competitiveness, thus distributing countries into five different categories, according to the stage of their economic competitiveness, reported in their annual Global Competitiveness Report (Kharlamova and Vertelieva, 2013).

\section{COMPETITIVENESS ACROSS THE EUROPEAN UNION MEMBER COUNTRIES}

Since the EU report in 2012, the EU economic performance seems to have improved, despite the strong economic and financial downturn that has been recorded in the aftermath of the crisis. Modest growth has been recorded as an outcome of fiscal consolidation, labor market, and financial sector amelioration, gradually restoring the confidence and bringing back on track even the economies that have suffered the most in this storm. Nevertheless, with an average index of 4.83, the EU lags behind the rest of the world, in terms of tracing the road towards smart growth (Schwab, 2017). Falling behind in building the innovationbased economy, compared to the other leading economies, is noticed in respect to all four areas of smart growth. Accordingly, with fewer competitive forces, rigid regulation, and enough dedicated funds for start-ups, the EU is found to provide less favorable conditions to support business development.

Similarly, the EU has not achieved significant results in terms of enforcing the digital infrastructure and boosting its innovation capacities, which have affected its competitiveness accordingly. In this context, as evidenced through the EU competitiveness report in 2014, the expenditures for Research \& Development, accounted for $1.6 \%$ of the EU GDP and were found to be significantly behind the ones of the US $(2.8 \%)$ as well as much behind the EU 2020 target of $3 \%$. A similar pattern has been recorded, when it comes to a process of patent application within the industries, suggesting the existence of the capacity and knowledge gap in their implementation.

Along with such a performance of the EU economy, it is worth mentioning that the individual EU countries have not performed equally, in terms of their competitiveness and achievement of Europe 2020 goals. Respectively, while some EU countries have performed better, compared to the US and other global economic leaders, reaching the values that outperform the EU average, others still lag. Accordingly, Northern and Western European countries, identified as innovative economies, have reported expenditures in Research \& Development in the amount of $3.4 \%$ of the 
GDP, whereas the Southern and Eastern European countries reached only $1 \%$. Moreover, results across the EU countries have been far from homogenous and remarkable in terms of patent applications, being 16 times higher in the first group, as well as in translating the results of fundamental research into tangible products and in their implementation. A similar pattern has been noticed regarding digitalization, being highly enforced within the Scandinavian countries that are much ahead, compared to the South-East members (World Economic Forum, 2014).

Filling this gap and achieving greater convergence among the EU countries has been one of the critical goals of the EU 2020 agenda in shaping the European structural policy reforms (European Commission, 2010a). However, following the empirical findings, there has been little consensus on what are the main sources of a country's economic progress being addressed through the prism of national competitiveness, particularly if studied in the context of EU integration. In this context, the study aims to evaluate the economic performance of nine chosen EU countries (France, Belgium, Italy, Germany, Netherlands, Luxemburg, Bulgaria, Romania, Croatia), reflected in GDP per capita, through the prism of its linkages with the country's international competitiveness, assessed through the Global Competitiveness Index framework for the period 2008-2017. In addition, the regression analysis, comparing the group of old (Belgium, France, Germany, Italy, Netherlands, Luxemburg) with the group of new member states (Bulgaria, Romania, Croatia), is performed, providing an insight into their competitiveness profile and the contributing power of the third-category competitiveness pillars (business sophistication \& innovation) to their performance.
The findings of the study enable a better understanding of differences between the clustered countries, concerning the role of Research \& Development and innovation in shaping their competitiveness and economic advancement, thus providing a foundation for assessing the challenges that the current EU countries and the potential new members are facing on their path toward convergence.

\section{LITERATURE REVIEW AND EMPIRICAL FINDINGS}

Theoretical literature and empirical findings on international competitiveness, as well as the relative importance of different factors and their contribution to the economic prosperity of states, are vast and versatile. The views range from those that competitiveness has an immense role in achieving the competitive advantage of a country and its economic advancement (Porter, 1990), to those that it could be "dangerous" for the socio-economic development of a nation (Krugman, 1994; Cerny, 1997) if competitiveness is an "obsession". Seen one way or another, the significance of building national competitiveness and maintaining its sustainability has attracted significant attention among scholars and policy-makers.

The concept of a country's competitiveness and its impact on the economic progress of a country has been examined through the prism of a variety of indicators. While many authors have approached this debate, assessing competitiveness based on its narrow definition (price and cost indicators, market shares, and trade balances), a rising number of scholars have directed their analysis on the non-price factors, emphasizing the key function of the Research \& Development, as well as 


\section{Journal of Contemporary Management Issues}

innovation, in driving international competitiveness, export performance and economic advancement of a country (Dunning 2000, Smith 2002; Di Mauro et al. 2005; Xu 2010; Tomas 2011, Xiong and Qureshi 2013, Jarreau and Poncet 2012; Oprescu 2012, Priede and Pereira 2013; Sandu and Ciocanel 2014; Kaimakoudi, Polymeros and Batzios 2014, Nachum, Silgoner et al. 2015, Rogic \& Mackic. 2017, Bugarčić \& Veselinović, 2020). A growing interest in this relationship, as explained by Smith (2002), is a consequence of the fact that we have entered a novel era of smart growth, empowered by the knowledge-driven industries. Accordingly, the economies should ground their growth on human capital and innovation as the key measures of their dominance in the contemporary business environment (Audretsch, et al. 2016; Szarowska 2017).

Empirical evidence, however, does not necessarily lead to conclusive findings, which is mostly a result of the wide range of definitions, diverse time intervals, sample size, methodology, and focus used in this analysis. In this view, Rodríguez-Pose and Crescenzi (2008) analyzed the linkages between the investment in R\&D activities, the number of patents, and the economic expansion of a country. The results confirmed a strong positive association between the increase in the number of patents and economic performance enhancement, being reflected in high-tech products export increase within the overall export of a country. Such a relationship was particularly observed in the more patent-intensive industries and higher-income countries. In the same way, several authors (Hu and Pong 2009, Chu et al. 2012, Zeira 2011, Iwaisako and Futagami 2013) provided evidence on the crucial role of $R \& D$ investments and the patent availability for the economic expansion of a country.
Similarly, having assessed this relationship for 58 countries in the 1980-2003 period, Hasan and Tucci (2010) proved that economic growth is positively correlated with the increase in R\&D expenditures and patents. In addition, the study has examined the existence of such linkages between the $\mathrm{R} \& \mathrm{D}$ investments and high-tech products contribution to a rise in the overall exports. The study, however, revealed the existence of mixed results, with a positive relationship between the two variables in some of the EU countries and a negative relationship in other EU countries. The negative correlation results, occurring mostly in developed countries, could be explained by the cross-country product life pattern theory, according to which high technology goods production is found in developed countries only in the product introduction stage, while it moves to developing countries, in the declining stage of the product cycle. Following the same notion, Tudose and Rosu (2015) examined the dynamics of the selected EU countries' global competitiveness index, identifying the mixed impact of innovation on their economies' competitiveness. Accordingly, while only results for three countries (Austria, Spain, and Finland), were pointing out the negative impact of innovation on GCI, the conducive impact of innovation was recorded for Portugal, Romania, and Cyprus. On the contrary, while employing the principal component analysis in assessing this dependence, Simionescu (2015) did not find a significant impact of the $R \& D$ expenses and innovation on the competitiveness of Romania.

Aiming to assess the evidence in support of the belief that universities play an essential role in creating well-qualified human capital, Guerrero et al. (2016) proved that, for 12 EU countries with 102 universities, social factors, such as quality of human 
capital, have been more strongly associated with their regional competitiveness, as compared to economic factors, such as the GDP per capita. Having examined the key determinants of competitiveness and their impact on economic growth for several EU countries, Simionescu et al. (2017) confirmed the positive correlation between the education expenditure and economic expansion in a single country (Czech Republic), while the relationship between the R\&D expenditure and economic enhancement was revealed in Romania and Hungary. In this view, Kiselakova et al. (2018) found statistically significant evidence, supporting the premise on the positive correlation between the investments in $R \& D$ activities and the competitiveness progress in the global market, measured with the overall GCI score and its three main sub-indices dynamics for eleven Central and Eastern EU countries, within the 2007-2016 period. Accordingly, the correlation analysis results indicated the most significant dependence between the variables considered in the higher education sector.

Accordingly, it could be concluded that, aside from some EU countries with an observed negative correlation over the analyzed period, an increase in the gross domestic expenditures in $R \& D$ induces a rise of innovation, patents, and, finally, results in high-technology exports and economic growth of a country. However, as evidenced by Habanik et al. (2016), since the innovation potential, as one of the key performance factor,s still differs significantly among the EU countries, crucial steps would still need to be done towards changes in legislation, enhancing the financial incentives and linkages between the relevant stakeholders to ensure the knowledge-based growth and convergence across the EU.

\section{METHODOLOGY AND RESEARCH RESULTS}

This study aims to evaluate the competitiveness of the selected EU members, emphasizing the most advanced competitiveness factors. The subject of analysis relates to two groups of countries that joined the EU in a period of about 50 years, to contrast and compare their overall level of competitiveness and economic performance, and evaluate the contribution of innovation factors to the country's economic performance. These two groups include countries, entering the EU in 1958 (France, Italy, Germany, Netherlands, Luxemburg, and Belgium), and those that joined last in 2007 (Bulgaria and Romania) and 2013 (Croatia). The countries were selected, based on their accession date to the EU, to evaluate the link between the length of EU membership and countries' competitiveness and economic performance. In addition to basic requirements and efficiency enhancers sub-indices, characterized for the factordriven and efficiency-driven economies, the research was focused on the innovation and sophistication sub-index, being related to the highest level of competitiveness, or the innovation-driven economies, where the basic factors of production had already been exhausted. At this stage of development, the most powerful factor of competitiveness is the technological innovation, supported by strong R\&D in all sectors, as well as the establishment of quality science institutions, able to transform knowledge into new technologies. In this study, the observed period is from 2008 to 2017, based on the data available in the World Economic Forum and World Bank sources. The potential limitation of the analysis is a short observed period that cannot be extended, due to the changes in the WEF methodology. 


\section{Journal of Contemporary Management Issues}

To address the identified research goal, this study addresses the following research questions:

- How determining is the role of a country's competitiveness in achieving its economic prosperity?

- Are there differences in the overall competitiveness and its key drivers across the EU economies that joined the EU in different accession rounds?

- To which extent convergence has been achieved among the EU economies' international competitiveness?
- How important was the role of the third pillar factors (innovation and business sophistication) in contributing to the selected EU economies' international position?

Table 1 provides an overview of GDP per capita and the Global Competitiveness Index (GCI), the sub-indices: basic requirements, efficiency enhancers, and innovation and sophistication factors, as well as two pillars, belonging to the $3^{\text {rd }}$ sub-index - business sophistication and $R \& D$ innovation, for the 2008-2017 period, in the selected EU countries.

Table 1. GDP per capita, Global Competitiveness Index (GCI), and sub-indexes (2008-2017)

\begin{tabular}{|c|c|c|c|c|c|c|c|c|c|c|c|}
\hline & Indicator Name & 2008 & 2009 & 2010 & 2011 & 2012 & 2013 & 2014 & 2015 & 2016 & 2017 \\
\hline & GDP per capita & 44,881 & 44,380 & 47,703 & 44,741 & 46,583 & 47,352 & 40,361 & 41,261 & 43,324 & 44,881 \\
\hline & GCI & 5.14 & 5.09 & 5.07 & 5.20 & 5.21 & 5.13 & 5.18 & 5.20 & 5.25 & 5.23 \\
\hline & $\begin{array}{l}\text { 1.Basic } \\
\text { requirements } \\
\text { (Subindex 1) }\end{array}$ & 5.60 & 5.43 & 5.45 & 5.58 & 5.52 & 5.51 & 5.53 & 5.56 & 5.56 & 5.50 \\
\hline & $\begin{array}{l}\text { 2.Efficiency } \\
\text { enhancers } \\
\text { (Subindex 2) }\end{array}$ & 5.02 & 5.04 & 5.01 & 5.13 & 5.09 & 5.03 & 5.07 & 5.09 & 5.18 & 5.10 \\
\hline & $\begin{array}{l}\text { 3. Innovation } \\
\text { and } \\
\text { sophistication } \\
\text { factors } \\
\text { (Subindex 3) }\end{array}$ & 5.02 & 4.95 & 4.91 & 5.06 & 5.21 & 5.07 & 5.11 & 5.14 & 5.16 & 5.20 \\
\hline & $\begin{array}{l}\text { 3.1 Business } \\
\text { sophistication }\end{array}$ & 5.36 & 5.28 & 5.24 & 5.30 & 5.32 & 5.27 & 5.34 & 5.33 & 5.35 & 5.40 \\
\hline$\frac{\vec{E}}{\frac{\overrightarrow{E D}}{\tilde{D}}}$ & $\begin{array}{r}3.2 R \& D \\
\text { Innovation }\end{array}$ & 4.69 & 4.62 & 4.49 & 4.83 & 5.09 & 4.87 & 4.89 & 4.96 & 4.97 & 5.00 \\
\hline & GDP per capita & 41,575 & 40,638 & 43,791 & 40,875 & 42,593 & 43,009 & 36,613 & 36,870 & 38,477 & 41,575 \\
\hline & GCI & 5.22 & 5.13 & 5.13 & 5.14 & 5.11 & 5.05 & 5.08 & 5.13 & 5.20 & 5.18 \\
\hline & 1. Subindex 1 & 5.76 & 5.60 & 5.67 & 5.57 & 5.52 & 5.50 & 5.42 & 5.48 & 5.54 & 5.50 \\
\hline & 2. Subindex 2 & 5.09 & 5.08 & 5.09 & 5.09 & 5.04 & 5.00 & 5.07 & 5.08 & 5.14 & 5.10 \\
\hline & 3. Subindex 3 & 5.08 & 4.90 & 4.83 & 4.93 & 4.96 & 4.84 & 4.86 & 4.97 & 5.07 & 5.10 \\
\hline & $\begin{array}{l}3.1 \text { Business } \\
\text { sophistication }\end{array}$ & 5.50 & 5.30 & 5.18 & 5.14 & 5.00 & 5.00 & 4.98 & 5.06 & 5.22 & 5.20 \\
\hline $\begin{array}{l}\text { 苛 } \\
\text { 营 }\end{array}$ & $\begin{array}{r}3.2 \mathrm{R} \& \mathrm{D} \\
\text { Innovation }\end{array}$ & 4.67 & 4.50 & 4.48 & 4.72 & 4.91 & 4.68 & 4.74 & 4.88 & 4.92 & 4.90 \\
\hline
\end{tabular}


Management, Vol. 26, 2021, Special Issue, pp. 45-62 J. Stanojević, G. Veličković: ASSESSING INTERNATIONAL COMPETITIVENESS ...

\begin{tabular}{|c|c|c|c|c|c|c|c|c|c|c|c|}
\hline \multirow{7}{*}{ 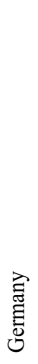 } & GDP per capita & 41,733 & 41,786 & 46,810 & 44,065 & 46,531 & 48,043 & 41,324 & 42,233 & 44,470 & 41,733 \\
\hline & GCI & 5.46 & 5.37 & 5.39 & 5.41 & 5.48 & 5.51 & 5.49 & 5.53 & 5.57 & 5.65 \\
\hline & 1. Subindex 1 & 5.96 & 5.85 & 5.89 & 5.83 & 5.86 & 5.90 & 5.91 & 5.95 & 5.94 & 6.00 \\
\hline & 2. Subindex 2 & 5.22 & 5.12 & 5.11 & 5.18 & 5.27 & 5.31 & 5.28 & 5.31 & 5.40 & 5.50 \\
\hline & 3. Subindex 3 & 5.54 & 5.47 & 5.51 & 5.53 & 5.57 & 5.59 & 5.56 & 5.61 & 5.61 & 5.60 \\
\hline & $\begin{array}{l}3.1 \text { Business } \\
\text { sophistication }\end{array}$ & 5.87 & 5.82 & 5.82 & 5.66 & 5.71 & 5.68 & 5.65 & 5.70 & 5.64 & 5.60 \\
\hline & $\begin{array}{r}3.2 \mathrm{R} \& \mathrm{D} \\
\text { Innovation }\end{array}$ & 5.22 & 5.11 & 5.19 & 5.39 & 5.42 & 5.50 & 5.47 & 5.51 & 5.58 & 5.60 \\
\hline \multirow[b]{7}{*}{ 离 } & GDP per capita & 36,977 & 35,849 & 38,335 & 34,814 & 35,370 & 35,397 & 30,180 & 30,669 & 31,953 & 36,977 \\
\hline & GCI & 4.35 & 4.31 & 4.37 & 4.43 & 4.46 & 4.41 & 4.42 & 4.46 & 4.50 & 4.54 \\
\hline & 1. Subindex 1 & 4.53 & 4.38 & 4.84 & 4.84 & 4.81 & 4.85 & 4.82 & 4.80 & 4.86 & 4.90 \\
\hline & 2. Subindex 2 & 4.38 & 4.37 & 4.33 & 4.41 & 4.44 & 4.34 & 4.35 & 4.39 & 4.43 & 4.50 \\
\hline & 3. Subindex 3 & 4.19 & 4.15 & 4.11 & 4.18 & 4.24 & 4.22 & 4.26 & 4.35 & 4.39 & 4.50 \\
\hline & $\begin{array}{l}3.1 \text { Business } \\
\text { sophistication }\end{array}$ & 4.99 & 4.92 & 4.81 & 4.85 & 4.75 & 4.74 & 4.79 & 4.84 & 4.84 & 4.90 \\
\hline & $\begin{array}{l}3.2 \mathrm{R} \& \mathrm{D} \\
\text { Innovation }\end{array}$ & 3.38 & 3.38 & 3.40 & 3.51 & 3.73 & 3.69 & 3.43 & 3.86 & 3.93 & 4.00 \\
\hline \multirow{7}{*}{ 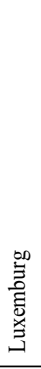 } & GDP per capita & 103,199 & 104,965 & 115,762 & 106,749 & 113,625 & 119,225 & 101,447 & 100,739 & 104,103 & 103,199 \\
\hline & GCI & 4.85 & 4.96 & 5.05 & 5.03 & 5.09 & 5.09 & 5.17 & 5.20 & 5.20 & 5.23 \\
\hline & 1. Subindex 1 & 5.78 & 5.85 & 5.81 & 5.90 & 5.96 & 5.87 & 6.02 & 5.95 & 5.95 & 6.00 \\
\hline & 2. Subindex 2 & 4.69 & 4.84 & 4.92 & 4.89 & 4.87 & 4.92 & 4.97 & 5.00 & 4.99 & 5.00 \\
\hline & 3. Subindex 3 & 4.51 & 4.58 & 4.76 & 4.75 & 4.89 & 4.84 & 4.93 & 5.04 & 5.07 & 5.10 \\
\hline & $\begin{array}{l}3.1 \text { Business } \\
\text { sophistication }\end{array}$ & 4.87 & 4.85 & 4.98 & 4.98 & 4.96 & 4.98 & 5.00 & 5.10 & 5.21 & 5.20 \\
\hline & $\begin{array}{r}3.2 \mathrm{R} \& \mathrm{D} \\
\text { Innovation }\end{array}$ & 4.15 & 4.31 & 4.53 & 4.52 & 4.82 & 4.70 & 4.85 & 4.98 & 4.73 & 5.00 \\
\hline \multirow{7}{*}{ 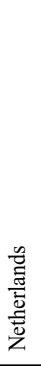 } & GDP per capita & 51,900 & 50,338 & 53,541 & 49,475 & 51,574 & 52,157 & 44,746 & 45,638 & 48,223 & 51,900 \\
\hline & GCI & 5.41 & 5.32 & 5.33 & 5.41 & 5.50 & 5.42 & 5.45 & 5.50 & 5.57 & 5.66 \\
\hline & 1. Subindex 1 & 5.81 & 5.71 & 5.82 & 5.88 & 5.92 & 5.89 & 5.95 & 6.05 & 6.12 & 6.20 \\
\hline & 2. Subindex 2 & 5.38 & 5.26 & 5.24 & 5.29 & 5.35 & 5.27 & 5.28 & 5.31 & 5.38 & 5.50 \\
\hline & 3. Subindex 3 & 5.20 & 5.17 & 5.16 & 5.30 & 5.42 & 5.36 & 5.41 & 5.61 & 5.52 & 5.60 \\
\hline & $\begin{array}{l}3.1 \text { Business } \\
\text { sophistication }\end{array}$ & 5.58 & 5.54 & 5.55 & 5.58 & 5.63 & 5.56 & 5.57 & 5.56 & 5.61 & 5.70 \\
\hline & $\begin{array}{r}3.2 \mathrm{R} \& \mathrm{D} \\
\text { Innovation }\end{array}$ & 4.82 & 4.79 & 4.77 & 5.03 & 5.31 & 5.16 & 5.25 & 5.37 & 5.44 & 5.60 \\
\hline \multirow{7}{*}{ 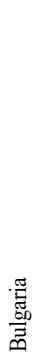 } & GDP per capita & 6,970 & 6,843 & 7,814 & 7,378 & 7,675 & 7,853 & 6,993 & 7,469 & 8,032 & 6,970 \\
\hline & $\mathrm{GCI}$ & 4.03 & 4.02 & 4.13 & 4.16 & 4.27 & 4.31 & 4.37 & 4.32 & 4.44 & 4.46 \\
\hline & 1. Subindex 1 & 4.2 & 4.13 & 4.43 & 4.46 & 4.63 & 4.73 & 4.71 & 4.57 & 4.67 & 4.80 \\
\hline & 2. Subindex 2 & 4.05 & 4.08 & 4.07 & 4.10 & 4.18 & 4.18 & 4.31 & 4.31 & 4.43 & 4.40 \\
\hline & 3. Subindex 3 & 3.30 & 3.29 & 3.22 & 3.24 & 3.30 & 3.28 & 3.27 & 3.37 & 3.57 & 3.60 \\
\hline & $\begin{array}{c}3.1 \text { Business } \\
\text { sophistication }\end{array}$ & 3.69 & 3.68 & 3.52 & 3.55 & 3.62 & 3.59 & 3.61 & 3.64 & 3.78 & 3.80 \\
\hline & $\begin{array}{r}3.2 \mathrm{R} \& \mathrm{D} \\
\text { Innovation }\end{array}$ & 2.91 & 2.90 & 2.91 & 2.94 & 2.98 & 2.97 & 2.94 & 3.11 & 3.36 & 3.30 \\
\hline
\end{tabular}




\section{Journal of Contemporary Management Issues}

\begin{tabular}{|l|l|l|l|l|l|l|l|l|l|l|l|}
\hline & GDP per capita & 8,475 & 8,231 & 9,151 & 8,558 & 9,585 & 10,020 & 8,978 & 9,532 & 10,814 & 8,475 \\
\hline GCI & 4.10 & 4.11 & 4.16 & 4.08 & 4.07 & 4.13 & 4.30 & 4.32 & 4.30 & 4.28 \\
\hline 1. Subindex 1 & 4.15 & 4.10 & 4.36 & 4.28 & 4.22 & 4.32 & 4.48 & 4.55 & 4.55 & 4.60 \\
\hline 2. Subindex 2 & 4.18 & 4.25 & 4.18 & 4.09 & 4.12 & 4.13 & 4.32 & 4.37 & 4.28 & 4.30 \\
\hline 3. Subindex 3 & 3.53 & 3.44 & 3.24 & 3.20 & 3.20 & 3.32 & 3.53 & 3.48 & 3.35 & 3.30 \\
\hline $\begin{array}{c}\text { 3.1 Business } \\
\text { sophistication }\end{array}$ & 3.93 & 3.79 & 3.55 & 3.48 & 3.47 & 3.62 & 3.77 & 3.71 & 3.56 & 3.50 \\
\hline $\begin{array}{c}3.2 \text { R\&D } \\
\text { Innovation }\end{array}$ & 3.14 & 3.10 & 2.94 & 2.91 & 2.92 & 3.01 & 3.28 & 3.24 & 3.14 & 3.10 \\
\hline \multirow{2}{*}{ GDP per capita } & 14,157 & 13,543 & 14,571 & 13,255 & 13,649 & 13,597 & 11,758 & 12,299 & 13,295 & 14,157 \\
\hline & 4.22 & 4.03 & 4.04 & 4.08 & 4.04 & 4.13 & 4.13 & 4.07 & 4.15 & 4.19 \\
\hline GCI & 1. Subindex 1 & 4.69 & 4.62 & 4.78 & 4.76 & 4.68 & 4.69 & 4.66 & 4.56 & 4.60 & 4.80 \\
\hline 2. Subindex 2 & 4.08 & 4.05 & 3.97 & 4.01 & 4.01 & 4.05 & 4.11 & 4.05 & 4.09 & 4.10 \\
\hline 3. Subindex 3 & 3.7 & 3.69 & 3.32 & 3.37 & 3.39 & 3.46 & 3.47 & 3.43 & 3.41 & 3.40 \\
\hline $\begin{array}{c}\text { 3.1 Business } \\
\text { sophistication }\end{array}$ & 3.98 & 3.76 & 3.56 & 3.66 & 3.66 & 3.81 & 3.83 & 3.74 & 3.76 & 3.80 \\
\hline $\begin{array}{c}\text { 3.2 R\&D } \\
\text { Innovation }\end{array}$ & 3.41 & 3.22 & 3.08 & 3.09 & 3.12 & 3.12 & 3.10 & 3.13 & 3.06 & 2.90 \\
\hline
\end{tabular}

Source: World Bank \& Global Competitiveness Report, World Economic Forum, 2009-2018

Based on data, provided in Table 1, there is a clear gap in the economic performance of the selected EU countries. Namely, the oldest EU member countries (Belgium, France, Germany, Italy, Netherlands, and Luxemburg) have several times larger GDP per capita, compared to the newest EU members (Bulgaria, Romania, and Croatia). Furthermore, the highest value of GCI among the selected EU counties in the observed period is recorded for Germany and the Netherlands. Both countries have the highest values, not only in the overall GCI but also for the $b a$ sic requirements, efficiency enhancers, and innovations and sophistication factors, as well as in two pillars, under the $3^{\text {rd }}$ sub-index (business sophistication and $R \& D$ innovation). Among the first group of countries, joining the EU in 1958, Italy, with the lowest values in all indicators, is struggling with an unsatisfactory level of competitiveness. However, these low values of competitiveness indicators in Italy are still above the values for the same indicators in the second group of countries (joining in 2007 and 2013). Although Bulgaria, Romania, and Croatia lag behind the initial EU member countries regarding competitiveness, as a group, they have very similar values across all indicators. 


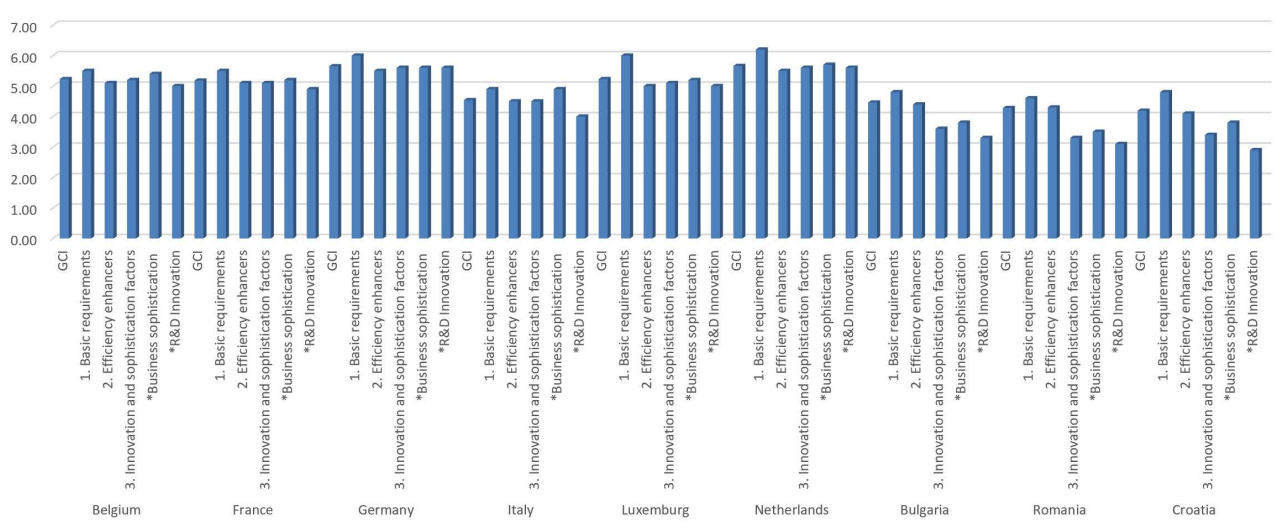

Figure 2. Selected EU countries according to the GCI and its sub-indexes in 2017

Source: Global Competitiveness Report, World Economic Forum, 2009-2018.

The main difference between these two groups of countries, besides the overall level of competitiveness, is reflected in the level of achieved competitiveness within three sub-indices. In the countries with a higher level of competitiveness joining the EU at the very beginning of its establishment, the value of all indicators is close. There is a similar score of the overall GCI, its sub-indices, and pillars within the last sub-index. On the other hand, in the second group of countries that includes the newest EU members (Croatia, Romania, and Bulgaria), the value of the $3^{\text {rd }}$ sub-index, related to the innovations and sophistication factors, is lower to some extent than the value of basic requirements and efficiency enhancers. Within this sub-index, the value is especially low for $R \& D$ innovation, indicating an insufficient level of technological innovations, research and development, and investment in scientific institutions for developing new technologies, and, thus, the need for further improvement regarding innovations.
Aiming to evaluate the relationship between $R \& D$ innovation and business sophistication, as two pillars within the $3^{\text {rd }}$ sub-index, and simultaneously the country's economic performance, measured by the GDP per capita, the regression analysis was performed. The purpose of the regression analysis, as an often-used statistical and analytical tool, is to elaborate the relationship between a dependant variable (in this case, the GDP per capita) and one or more independent variables (R\&D innovation and business sophistication), being measured on the same scale (Soldic-Aleksic, 2015). The regression analysis determines the strength of the independent variable impact, providing a deeper understanding of the importance that innovation, as the most advanced competitiveness factor, has on the overall national competitiveness and economic performance. Tables 2 and 3 show the results of the regression analysis. 


\section{Journal of Contemporary Management Issues}

Table 2. Results of the regression analysis for the selected EU countries

\begin{tabular}{|l|l|l|l|l|l|l|l|l|l|l|}
\hline \multirow{2}{*}{ Model } & \multirow{2}{*}{$\mathbf{R}$} & \multirow{2}{*}{$\begin{array}{c}\mathbf{R} \\
\text { Square }\end{array}$} & \multirow{2}{*}{$\begin{array}{c}\text { Adj. R } \\
\text { Square }\end{array}$} & $\begin{array}{l}\text { Std. Error of } \\
\text { the Estimate }\end{array}$ & & & \multicolumn{5}{|c|}{$\begin{array}{c}\text { Change Statistics } \\
\text { Change }\end{array}$} & $\begin{array}{c}\text { F } \\
\text { Change }\end{array}$ & df1 & df2 & $\begin{array}{c}\text { Sig. F } \\
\text { Change }\end{array}$ & $\begin{array}{l}\text { Durbin- } \\
\text { Watson }\end{array}$ \\
\hline 1 & $.334^{\mathrm{a}}$ & .111 & .143 & 2889.17515 & .111 & .438 & 2 & 7 & .662 & 1.556 \\
\hline 2 & $.561^{\mathrm{a}}$ & .315 & .028 & 2951.30467 & .315 & .919 & 3 & 6 & .486 & 1.704 \\
\hline 3 & $.715^{\mathrm{a}}$ & .512 & .268 & 2083.38449 & .512 & 2.098 & 3 & 6 & .202 & 1.001 \\
\hline 4 & $.874^{\mathrm{a}}$ & .763 & .645 & 1978.88447 & .763 & 6.441 & 3 & 6 & .026 & 1.564 \\
\hline 5 & $.479^{\mathrm{a}}$ & .229 & .156 & 7173.18619 & .229 & .594 & 3 & 6 & .641 & 2.470 \\
\hline 6 & $.788^{\mathrm{a}}$ & .622 & .432 & 2744.29596 & .622 & 3.286 & 3 & 6 & .100 & 2.003 \\
\hline 7 & $.442^{\mathrm{a}}$ & .196 & .207 & 452.67665 & .196 & .486 & 3 & 6 & .704 & 2.194 \\
\hline 8 & $.468^{\mathrm{a}}$ & .219 & .171 & 926.91256 & .219 & .561 & 3 & 6 & .660 & 1.778 \\
\hline 9 & $.636^{\mathrm{a}}$ & .405 & .107 & 1082.63041 & .405 & 1.361 & 3 & 6 & .341 & 1.534 \\
\hline
\end{tabular}

1. Belgium: a. Predictors: (Constant), R\&D Innovation, Business sophistication

2. France: a. Predictors: (Constant), R\&D Innovation, Business sophistication

3. Germany: a. Predictors: (Constant), R\&D Innovation, Business sophistication

4. Italy: a. Predictors: (Constant), R\&D Innovation, Business sophistication

5. Luxemburg: a. Predictors: (Constant), R\&D Innovation, Business sophistication

6. Netherlands: a. Predictors: (Constant), R\&D Innovation, Business sophistication

7. Bulgaria: a. Predictors: (Constant), R\&D Innovation, Business sophistication

8. Romania: a. Predictors: (Constant), R\&D Innovation, Business sophistication

9. Croatia: a. Predictors: (Constant), R\&D Innovation, Business sophistication

Note: Dependent variable for all analyzed countries is gross domestic product per capita

Source: Authors' calculation

The multiple correlation coefficient $\mathrm{R}$ from Table 2 shows the linear correlation between predictors $(R \& D$ innovation and business sophistication) and GDP per capita as the dependant variable. Its high values for Germany, Italy, Netherlands, and
Croatia indicate an intense link between $R \& D$ innovation and business sophistication, and GDP per capita, confirming the importance of innovations for the economic growth of a country. 
Table 3. Regression analysis - coefficients

\begin{tabular}{|c|c|c|c|c|c|c|c|c|c|c|}
\hline \multirow{2}{*}{ Model } & \multicolumn{2}{|c|}{$\begin{array}{l}\text { Unstandardized } \\
\text { Coefficients }\end{array}$} & \multirow{2}{*}{\begin{tabular}{|c|}
$\begin{array}{c}\text { Standard. } \\
\text { Coeff. }\end{array}$ \\
Beta \\
\end{tabular}} & \multirow{2}{*}{$\mathbf{t}$} & \multirow{2}{*}{ Sig. } & \multicolumn{3}{|c|}{ Correlations } & \multicolumn{2}{|c|}{$\begin{array}{c}\text { Collinearity } \\
\text { Statistics }\end{array}$} \\
\hline & B & Std. Error & & & & $\begin{array}{l}\text { Zero- } \\
\text { order }\end{array}$ & $\begin{array}{c}\text { Par- } \\
\text { tial }\end{array}$ & Part & Tolerance & VIF \\
\hline 1 (Constant) & 125724.560 & 133908.751 & & .939 & .384 & & & & & \\
\hline $\begin{array}{l}\text { Business } \\
\text { sophistication }\end{array}$ & 37944.928 & 39803.821 & .667 & .953 & .377 & .163 & .363 & .334 & .251 & 3.990 \\
\hline R\&D Innovation & 38242.022 & 39379.208 & 2.652 & .971 & .369 & .330 & .369 & .340 & .016 & 60.884 \\
\hline 2 (Constant) & 69300.747 & 54343.348 & & 1.275 & .249 & & & & & \\
\hline $\begin{array}{l}\text { Business } \\
\text { sophistication }\end{array}$ & 18096.475 & 35101.203 & 1.004 & .516 & .625 & .233 & .206 & .174 & .030 & 33.208 \\
\hline R\&D Innovation & 8770.031 & 37079.905 & .493 & .237 & .821 & .532 & .096 & .080 & .026 & 37.979 \\
\hline 3 (Constant) & 371039.484 & 182469.428 & & 2.033 & .088 & & & & & \\
\hline $\begin{array}{l}\text { Business } \\
\text { sophistication }\end{array}$ & 219501.846 & 107413.224 & 8.155 & 2.044 & .087 & .300 & .641 & .583 & .005 & 195.771 \\
\hline R\&D Innovation & 241215.085 & 110853.146 & 16.854 & 2.176 & .072 & .217 & .664 & .621 & .001 & 737.477 \\
\hline 4 (Constant) & 45810.215 & 46355.023 & & .988 & .361 & & & & & \\
\hline $\begin{array}{l}\text { Business } \\
\text { sophistication }\end{array}$ & 11137.892 & 10295.794 & .260 & 1.082 & .321 & .341 & .404 & .215 & .684 & 1.462 \\
\hline R\&D Innovation & 6671.590 & 7239.710 & .486 & .922 & .392 & .846 & .352 & .183 & .142 & 7.036 \\
\hline 5 (Constant) & 218672.512 & 165270.715 & & 1.323 & .234 & & & & & \\
\hline $\begin{array}{l}\text { Business } \\
\text { sophistication }\end{array}$ & 8908.593 & 96851.201 & .163 & .092 & .930 & .445 & .038 & .033 & .041 & 24.539 \\
\hline R\&D Innovation & 18230.514 & 49997.591 & .765 & .365 & .728 & .237 & .147 & .131 & .029 & 34.264 \\
\hline 6 (Constant) & 55305.028 & 206651.952 & & .268 & .798 & & & & & \\
\hline $\begin{array}{l}\text { Business } \\
\text { sophistication }\end{array}$ & 18952.609 & 32957.089 & .249 & .575 & .586 & .281 & .229 & .144 & .337 & 2.965 \\
\hline R\&D Innovation & 1352.413 & \begin{tabular}{|l|}
16939.412 \\
\end{tabular} & .108 & .080 & .939 & .691 & .033 & .020 & .034 & 29.255 \\
\hline 7 (Constant) & \begin{tabular}{|l|l|}
7847.847 \\
\end{tabular} & 7685.076 & & 1.021 & .347 & & & & & \\
\hline $\begin{array}{l}\text { Business } \\
\text { sophistication }\end{array}$ & 5171.092 & 6958.286 & 1.145 & .743 & .485 & .257 & .290 & .272 & .056 & 17.712 \\
\hline R\&D Innovation & 3970.756 & 6081.341 & 1.626 & .653 & .538 & .329 & .258 & .239 & .022 & 46.231 \\
\hline 8 (Constant) & 828.643 & 8234.285 & & .101 & .923 & & & & & \\
\hline $\begin{array}{l}\text { Business } \\
\text { sophistication }\end{array}$ & 1258.331 & 38039.900 & .228 & .033 & .975 & .232 & .014 & .012 & .003 & 366.084 \\
\hline R\&D Innovation & 2849.824 & 41011.967 & .433 & .069 & .947 & .460 & .028 & .025 & .003 & 298.665 \\
\hline 9 (Constant) & 6643.987 & 12392.090 & & .536 & .611 & & & & & \\
\hline $\begin{array}{l}\text { Business } \\
\text { sophistication }\end{array}$ & 592.063 & 4628.026 & .059 & .128 & .902 & .407 & .052 & .040 & .465 & 2.150 \\
\hline R\&D Innovation & 4015.117 & 4540.775 & .451 & .884 & .411 & .619 & .340 & .278 & .381 & 2.621 \\
\hline
\end{tabular}

Note: Dependent Variable: Gross domestic product per capita.

Source: Authors' calculation.

The contribution of the $R \& D$ innovation and the business sophistication to GDP per capita was examined in Table 3. $\beta$ coefficient shows that the $R \& D$ innovation has a higher contribution to the country's economic position, indicated by gross domestic product per capita. Only in the case of France and the Netherlands, business sophistication contributes more than $R \& D$ innovation. 


\section{Journal of Contemporary Management Issues}

\section{CONCLUSION AND RECOMMENDATIONS}

The importance of a country's competitiveness was addressed by many scholars aiming to assess the extent to which this concept is associated with the social welfare and economic prosperity of a country. Regardless of the lens, through which this multidimensional concept is explained, empirical findings, related to these linkages are not conclusive, particularly if seen through the lens of EU integration. Even though the EU, as suggested by the Global Competitiveness Report (Schwab, 2014), has recorded a meaningful recovery of its economy after the financial crisis and the fact that its GCI has increased, it still lags behind the rest of the key players in the global market in terms of achieving the innovation-driven, smart growth. This is particularly true, when it comes to some EU country members and sophisticated industries, given the fact that weak cohesion in economic growth, competitiveness, and success towards reaching Europe 2020 targeted goals have been evidenced. However, despite the growing interest and policymakers concern in this regard, not enough attention has been given to assessing such disparities within the EU framework.

In this context, the study aimed to evaluate the economic performance of selected oldest and newest EU member countries, indicated by gross domestic product per capita, through the lens of international competitiveness. The study analyzed their association and the relative importance of several competitiveness factors, particularly those reflecting their innovation capacity, in reaching economic advancement. Empirical results of the comparative study confirmed the gap in the economic development between these two groups of EU countries, measured by GDP per capita, as well as in the overall competitiveness, measured by GCI. Similarly, along with the overall level of competitiveness, differences between these two groups of countries are also revealed in the level of achieved competitiveness within the three sub-indices, suggesting the diverse relative importance of the three pillars factors to their competitiveness. Accordingly, while for the countries that first joined the EU, we identified the similar value of the GCI sub-indices, for the newly accessed countries, the value of the $3^{\text {rd }}$ sub-index (innovations and sophistication factors) is, to some extent, lower, implying an insufficient level of technological innovation, research and development investments and the need for further improvement in this regard. The regression analysis results confirmed that research and development have a significant impact on the country's economic performance and overall competitiveness. However, the identified differences, in terms of the dependence strength between the two variables across the EU countries, pointed out the need for better implementation of the third pillar's factors towards the enhancement of their economic performance.

Given these findings, one could conclude that, despite the convergence process within the EU, the significant disparities in the competitiveness of individual economies and their key drivers, still prevail. The gap in building an innovation-based economy is evidenced accordingly between these two analyzed groups of member states, concerning all areas of smart growth. Being characterized by less competitive markets, more rigid regulation, and fewer funds for start-ups and R\&D, the new EU members provide less favorable conditions to support innovation and business development.

Diminishing the differences in the international competitiveness and economic 
performance drivers and enhancing the efforts toward achieving greater cohesion in smart, innovation-driven, sustainable growth across the EU members would require coordinated engagement from all stakeholders. Accordingly, larger investments in R\&D, information and communication technologies, skills development, and enhancing the quality of education and its connection to industry, while being supported and monitored with enough institutional capacity and effective governance mechanisms, would ensure a more innovative and competitive business environment. Having these prioritized in the economic development agenda of new EU member countries, that are significantly falling behind, should be a necessity, ensuring a more innovative and competitive business environment in assessing countries, their successful convergence, a stronger and more coherent smart growth within the EU.

The potential limitation of this study arises from the fact that research results rely on the data available in the WEF reports and the fact that analysis included a short observed period that could not be extended due to the changes in the WEF methodology. To overcome these limitations in future research, other sources (s) of data could be considered, allowing for a wider range of data across the EU countries and across a longer period.

\section{REFERENCES}

1. Aiginger, K., \& Landesmann, M. (2002). Competitive Economic Performance: USA versus EU. WIIW Research Reports, 291.

2. Audretsch, D., Lehmann, E., Meoli, M., \& Vismara, S. (2016). University evolution, entrepreneurial activity and regional competitiveness. Springer International Publishing.
3. Bugarčić, F., \& Veselinović, P. (2020). Openness of the economy as a determinant of economic growth: The panes analysis of the Western Balkans region countries. Economic Outlook, 22(2), $1-14$.

4. Cerny, P. G. (1997). Paradoxes of the competition state: The dynamics of political globalization. Government and Opposition, 32(2), 251-274.

5. Chu, A. C., Leung, C. K. Y., \& Tang, E. (2012). Intellectual Property Rights, Technical Progress and the Volatility of Economic Growth. Journal of Macroeconomics, 34, 749-756.

6. Di Mauro, F. (2005). Competitiveness and the export performance of the Euro Area. ECB Occasional Paper.

7. Dunning, J. H. (2000). Regions, Globalization, and the KnowledgeBased Economy. Oxford University Press.

8. European Commission (2010). Europe 2020: A strategy for smart, sustainable and inclusive growth. Bruxelles: European Commision.

9. Guerrero, M., Urbano, D., \& Fayolle, A. (2016). Entrepreneurial activity and regional competitiveness: Evidence from European entrepreneurial universities. The Journal of Technolog y Transfer, 41(1), 105-131.

10. Habanik, J., Kordos, M., \& Hostak, P. (2016). Competitiveness of Slovak Economy and Regional Development Policies. Journal of International Studies, 9(1), 144-155.

11. Hasan, I., \& Tucci, C. L. (2010). The innovation-economic growth nexus: Global evidence. Research Policy, 39, 1264-1276.

12. Hu, A. G., \& Png, I. P. L. (2009). Patent rights and economic growth: Cross-country evidence. In CELS 2009 


\section{Journal of Contemporary Management Issues}

4th Annual Conference on Empirical Legal Studies (p. 1).

13. Iwaisako, T., \& Futagami, K. (2013). Patent Protection, Capital Accumulation, and Economic Growth. Economic Theory, 52, 631-668.

14. Jarreau, J., \& Poncet, S. (2012). Export Sophistication and Economic Growth: Evidence from China. Journal of Development Economics, 97(2), 281-292.

15. Kaimakoudi, E., PolymerosK, \& Batzios, C. (2014). Investigating Export Performance and Competitiveness of Balkan and Eastern European Fisheries Sector. Procedia Economics and Finance, 9(219), 30.

16. Kharlamova, G. (2013). Investment security of Ukraine: Dynamics and forecast. The Problems of Economy, 1, 363-367.

17. Kharlamova, G., \& Vertelieva, O. (2013). The International Competitiveness of Countries: Economic-Mathematical Approach. Economics \& Sociology, 6(2), 39-52.

18. Kiselakova, D., Sofrankova, B., Cabinova, V., Onuferova, E., \& Soltesova, J. (2018). The Impact of R\&D Expenditure on the Development of Global Competitiveness within the CEE EU Countries. Journal of Competitiveness, 10(3), 34-50.

19. Kohler, W. (2006). The 'Lisbon goal' of the EU: Rhetoric or substance? Journal of Industry, Competition and Trade, 6(2), 85-113.

20. Krugman, P. (1994). Competitiveness: A dangerous obsession. Foreign Affairs, 73(2), 28-44.

21. Oprescu, R. (2012). Bridging intellectual capital and the competitiveness of nations. Management \& Marketing
Challenges for the Knowledge Society, 7(1), 73-88.

22. Porter, M. E. (1990). The competitive advantage of nations. Free Press, MacMillan.

23. Porter, M. E. (1998). Cluster and the new economics of competition. Harvard Business Review, 77-90.

24. Priede, J., \& Pereira, E. T. (2013). Innovation as a key factor in the international competitiveness of the European Union. European Integration Studies, 7:212-21.

25. Priede \& Neuertb. (2015). Competitiveness Gap of the European Union Member Countries in. The Context of Europe 2020 Strategy. Procedia Social and Behavioral Sciences, 207, 690-699.

26. Rodríguez-Pose, A., \& Crescenzi, R. (2008). Research and Development, Spillovers, Innovation Systems, and the Genesis of Regional Growth in Europe. Regional Studies, 42(1).

27. Rogic, L., \& Mackic, V. (2017). What Drives Competitiveness: The Case of New EU Member States. RSEP International Conferences on Social Issues and Economic Studies ISBN: 978-605-307-788-6 5th RSEP Social Sciences Conference.

28. Sandu, S., \& Ciocanel, B. (2014). Impact of R\&D and Innovation on High-Tech Export. Procedia Economics and Finance, 15(14), 80-90.

29. Schwab, K. (2014). The Global Competitiveness Report 2014-2015. World Economic Forum.

30. Schwab, K. (2017). The Global Competitiveness Report 2017-2018. World Economic Forum. 
31. Silgoner, M., Steiner, K., Wörz, J., \& Schitter, C. (2015). Fishing in the Same Pool: Export Strengths and Competitiveness of China and Central, Eastern and Southeastern Europe at the EU-15 Market. China Economic Review, 32, 68-83.

32. Simionescu, M. (2015). The regional competitiveness in Romania. A panel multivariate approach. Romanian Journal of Economics, 41(2 (50), 103-120.

33. Simionescu, M., Lazányi, K., Sopková, G., Dobeš, K., \& Balcerzak, A. P. (2017). Determinants of Economic Growth in V4 Countries and Romania. Journal of Competitiveness, 9(1), 103-116.

34. Smit, A. J. (2010). The competitive advantage of nations: Is Porter's Diamond Framework a new theory that explains the international competitiveness of countries? Southern African Business Review, 14(1), 105-130.

35. Smith, K. (2002). What is the 'knowledge economy'? Knowledge intensity and distributed knowledge bases. UNU/ INTECH Discussion Papers (June):32.

36. Soldic-Aleksic, J. (2015). Applied Data Analysis. University of Belgrade, Faculty of Economics.
37. Szarowska, I. (2017). Does Public R\&D Expenditure Matter for Economic Growth? GMM Approach. Journal of International Studies, 10(2), 90-103.

38. Tomas, V. (2011). National Competitiveness and Expenditure on Education. Research and Development. Journal of Competitiveness, 2:3-10.

39. Tudose, B. M., \& Rusu, V. D. (2015). Global competitiveness of the European Union member states: Evolution and perspectives. Studies and Scientific Researches. Economics Edition, 22.

40. Xiong, J., \& Qureshi, S. (2013). The Quality Measurement of China High-Technology Exports. Procedia Computer Science, 17, 290-297.

41. $\mathrm{Xu}, \mathrm{B}$. (2010). The Sophistication of Exports: Is China Special? China Economic Review, 21(3), 482-493.

42. World Economic Forum (2014). The Europe 2020 Competitiveness Report: Building a More Competitive Europe. Geneva: WEF.

43. Zeira, J. (2011). Innovations, Patent Races and Endogenous Growth. Journal of Economic Growth, 16, 135-156. 


\title{
PROCJENA MEĐUNARODNE KONKURENTNOSTI I NJEZINE ULOGE U OSTVARIVANJU EKONOMSKOG PROSPERITETA U KONTEKSTU INTEGRACIJE U EU
}

\begin{abstract}
Sažetak
Povećanje konkurentnosti u doba globalizacije postalo je ključnom temom u akademskim, kao i debatama o javnim politikama u svim suvremenim gospodarstvima. Ulogom nacionalne konkurentnosti bave se brojni istraživači, koji pokušavaju ocijeniti razinu do koje je ovaj concept povezan s pitanjima ekonomskog prosperiteta, kao što su socijalna sigurnost i privlačenje direktnih stranih investicija. Zajedno s ovom raspravom, postoji sve veći interes za razumijevanje poveznica između konkurentskih sila i zaostajanja u gospodarskom razvoju između zemalja - članica EU-a, a što predstavlja i jedno od ključnih pitanja u Europskoj Uniji. Prevladavanje ove razlike i postizanje više razine konvergencije između članica EU-a postao je jedan od kritičnih ciljeva u kreiranju europskih politika strukturnih reformi. Bez obzir na empirijske rezultate, po-

ekonomske performanse zemalja koje su se prve i posljednje pridružile EU, u odnosu prema nacionalnoj konkurentnosti. Pozornost se usmjerava na relativni značaj i doprinos čimbenika inovacije i sofisticiranosti poslovanja gospodarskom rastu tijekom promatranog perioda (2008-2017). Analiza se temelji na metodologiji Svjetskog ekonomskog foruma za mjerenje globalnog indeksa konkurentnosti i bazi podataka Svjetske banke. Rad se temelji na komparativnoj analizi, kao i regresiji, kojom se želi utvrditi odnos između konkurentnosti i indikatora gospodarske razvijenosti. Rezultati ukazuju na bolje razumijevanje značaja vremena pristupa EU-u za ukupnu konkurentnost $i$ gospodarske rezultate države te doprinosa inovacija u istraživanju i razvoju te sofisticiranosti poslovanja, kao složenijih čimbenika konkurentnosti, gospodarskom prosperitetu i razvoju.
\end{abstract} stoji niska razina slaganja oko ključnih izvora nacionalnog gospodarskog razvoja, promatrana kroz prizmu nacionalne konkurentnosti, posebno ako se analiziraju u kontekstu integracije $u$ EU. U navedenom kontekstu, ovaj rad analizira
Ključne riječi: gospodarski rezultati, međunarodna konkurentnost, čimbenici konkurentnosti, istraživanje i razvoj, inovacija, članice EU-a 